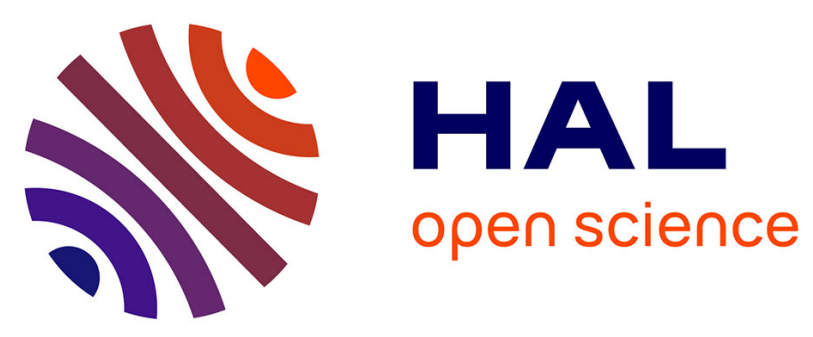

\title{
Mechanisms for variable expressivity of inherited SCN1A mutations causing Dravet syndrome
}

Christel Depienne, Oriane Trouillard, Isabelle Gourfinkel-An, Cécile Saint-Martin, Delphine Bouteiller, Denis Graber, Marie-Anne Barthez-Carpentier, Agnès Gautier, Nathalie Villeneuve, Marie-Odile Livet, et al.

\section{To cite this version:}

Christel Depienne, Oriane Trouillard, Isabelle Gourfinkel-An, Cécile Saint-Martin, Delphine Bouteiller, et al.. Mechanisms for variable expressivity of inherited SCN1A mutations causing Dravet syndrome. Journal of Medical Genetics, 2010, 47 (6), pp.404. 10.1136/jmg.2009.074328 . hal-00557383

\section{HAL Id: hal-00557383 https://hal.science/hal-00557383}

Submitted on 19 Jan 2011

HAL is a multi-disciplinary open access archive for the deposit and dissemination of scientific research documents, whether they are published or not. The documents may come from teaching and research institutions in France or abroad, or from public or private research centers.
L'archive ouverte pluridisciplinaire HAL, est destinée au dépôt et à la diffusion de documents scientifiques de niveau recherche, publiés ou non, émanant des établissements d'enseignement et de recherche français ou étrangers, des laboratoires publics ou privés. 


\section{Mechanisms for variable expressivity of inherited SCN1A mutations causing Dravet syndrome}

Christel Depienne, ${ }^{1,2,3^{*}}$ Oriane Trouillard, ${ }^{1}$ Isabelle Gourfinkel-An, ${ }^{4,5}$ Cécile Saint-Martin, ${ }^{2}$ Delphine Bouteiller, ${ }^{2}$ Denis Graber, ${ }^{6}$ Marie-Anne Barthez-Carpentier, ${ }^{7} \quad$ Agnès Gautier, ${ }^{8}$ Nathalie Villeneuve, ${ }^{9}$ Charlotte Dravet, ${ }^{9}$ Marie-Odile Livet, ${ }^{10}$ Clothilde Rivier-Ringenbach, ${ }^{11}$ Claude Adam, ${ }^{4}$ Sophie Dupont, ${ }^{4}$ Stéphanie Baulac, ${ }^{2,3}$ Delphine Héron, ${ }^{12}$ Rima Nabbout, ${ }^{5,13}$ and Eric LeGuern., ${ }^{1,2}$

${ }^{1}$ Unité Fonctionnelle de Neurogénétique Moléculaire et cellulaire, Département de Génétique et Cytogénétique, Centre de Génétique Moléculaire et chromosomique, AP-HP, GH Pitié-Salpêtrière, Paris, France; ${ }^{2}$ INSERM U 975, Paris, France; ${ }^{3}$ Université Pierre et Marie Curie, Centre de Recherche de l'institut du cerveau et de la moelle épinière, UMR_S975 Paris, France; ${ }^{4}$ Pôle d’Epileptologie, AP-HP, Groupe Hospitalier Pitié-Salpêtrière, Paris, France ; ${ }^{5}$ Centre de référence épilepsies rares, Paris, France ;

${ }^{6}$ Clinique de l’Enfant, Centre Hospitalier de la Rochelle, France ; ${ }^{7}$ Service de neuropédiatrique, Hôpital Gatien de Clocheville, CHRU de Tours, France; ${ }^{8}$ Clinique Médicale Pédiatrique, Hôpital Mère-Enfant, CHU de Nantes, France; ${ }^{9}$ Service de Neurologie, Hôpital Henri Gastaut, Marseille, France; ${ }^{10}$ Service de Pédiatrie, Centre Hospitalier du pays d’Aix, Aix-en-Provence, France; ${ }^{11}$ Service de pédiatreNéonatologie, Centre Hospitalier de Villefranche s/Saone, France; ${ }^{12}$ Unité Fonctionnelle de Génétique Clinique, Département de Génétique et Cytogénétique, AP-HP, GH Pitié-Salpêtrière, Paris, France; ${ }^{13}$ Département de Neuropédiatrie, AP-HP, Inserm U663, Hôpital Necker-Enfants malades, Paris, France.

* Correspondence to: Christel Depienne, INSERM U975 (CRicm), Bâtiment Pharmacie $4{ }^{\text {ème }}$ étage, Groupe Hospitalier Pitié-Salpêtrière, 47 boulevard de l'hôpital, 75013 Paris, France; e-mail : christel.depienne@upmc.fr 


\begin{abstract}
Background. Mutations in SCN1A can cause Genetic Epilepsy with Febrile Seizures Plus (GEFS+, inherited missense mutations) or Dravet syndrome (DS, de novo mutations of all types). Although the mutational spectra are distinct, these disorders share major features and $10 \%$ of DS patients have an inherited SCN1A mutation.
\end{abstract}

Objectives and patients. We studied 19 selected families with at least one DS patients to describe the mechanisms accounting for inherited SCN1A mutations in DS. The mutation identified in the DS probands was searched in available parents and relatives and quantified in the blood cells of the transmitting parent using quantitative allele-specific assays.

Results. Mosaicism in the blood cells of the transmitting parent was demonstrated in 12 cases and suspected in another case. The proportion of mutated allele in the blood varied from $0.04 \%$ to $85 \%$. In the 6 remaining families, six novel missense mutations were associated with autosomal dominant variable GEFS+ phenotypes including DS as the more severe clinical picture.

Conclusion. Our results indicate that mosaicism is found in at least $7 \%$ of families with at least one DS patient and that it accounts for $68 \%(13 / 19)$ of inherited mutations associated with DS. On the contrary, in the remaining cases $(6 / 19,32 \%)$, the patients were part of multiplex GEFS+ families and seemed to represent the extreme end of the GEFS+ clinical spectrum. In this latter case, additional genetic or environmental factors likely modulate the severity of the expression of the mutation. 
Dravet Syndrome (DS), previously known as severe myoclonic epilepsy in infancy (SMEI MIM\# 607208), is an epileptic encephalopathy with typical clinical features including onset of seizures before one year, generalized or hemiclonic seizures that are often prolonged and typically triggered by fever, and later apparition of polymorphic afebrile seizures that remain resistant to anti-epileptic treatments over time. The psychomotor development of the child, originally normal, becomes progressively delayed from age 2 and ataxia frequently develops [1, 2].

Genetic Epilepsy with Febrile Seizures Plus (previously described as Generalized Epilepsy with Febrile seizures plus or GEFS+, MIM\# 604233) is a variable autosomal dominant epileptic condition that also associates febrile and afebrile seizures. Affected family members present with phenotypes ranging from isolated febrile seizures to various idiopathic generalized epilepsy subtypes (epilepsy with grand mal seizures, childhood absence or juvenile myoclonic epilepsy) or can remain asymptomatic. The outcome is usually benign and patients are sensitive to classical anti-epileptic treatments. However, family members can occasionally experience focal seizures, be severely affected and/or pharmacoresistant, and even present with DS $[3,4,5,6]$.

Mutations in SCN1A, the gene encoding the neuronal sodium channel alpha I subunit (Nav1.1) were initially identified in GEFS+ families [7]. Shortly after, de novo SCN1A mutations were reported to be the major cause of DS, accounting for up to $80 \%$ of the patients $[8,9,10,11]$. Missense mutations are exclusively found in GEFS + whereas mutations associated with DS include all mutation types mutations as well as large rearrangements of the gene $[10,11,12,13,14,15]$. De novo missense mutations found in DS patients are never found in GEFS+ families, suggesting that the pathophysiological mechanisms are distinct in these disorders. Mutational spectrum in DS is compatible with a complete loss of function of the mutated allele (haploinsufficiency) [16]. The functional consequences of mutations associated with GEFS+, probably a gain or a partial loss of function, remain more controversial so far $[17,18,19,20,21$, 22]. Yet, DS and GEFS+ share major features, including sensitivity to seizures and polymorphous seizure types, and patients with DS have occasionally been reported in GEFS+ families, suggesting that DS could 
be at the severe end of the GEFS+ spectrum [23, 24, 25, 26, 27, 28]. On the contrary, patients with DS sometimes have a parent or relative with a milder epileptic phenotype and mutations inherited from an asymptomatic or mildly affected parent are identified in $10 \%$ of the DS patients [10, 29, 30, 31, 32, 33]. In 2006, we and others have shown that parental mosaicism can cause recurrent transmission of SCN1A mutations associated with DS [34, 35, 36, 37].

In this study, we investigated 19 families comprising at least one patient with DS in whom a SCN1A mutation was inherited. Our objectives were to estimate the frequency of parental mosaicism in a large cohort of DS patients and to determine whether other mechanisms could account for inherited SCN1A mutations in DS.

\section{Materials and Methods}

Patients, recruited in different French medical centres, were referred to our laboratory for molecular analysis of SCN1A [10]. We selected 19 index cases with DS who had an inherited SCN1A mutation based on molecular and/or familial arguments for further genetic investigations (Figure 1). Families 3, 4, 8, 11 and 13 included sib pairs with DS from healthy parents whereas families $1,2,5,6,7,9,12,14,15,16$, 17, 18 and 19 included a single patient with DS. In family 10, an elder child was deceased prematurely after a status epilepticus episode without a confirmed diagnosis of DS. Families 1, 5, 12, 14, 15, 16, 17, 18 and 19 also included one or more affected relative(s) with milder epilepsy compatible with GEFS+ condition (Figure 1A and 1B). In family 2 one parent had a single TCGS. Clinical features and mutations of families 3 and 11 were already reported [35]. Informed written consent was obtained from each individual before or his/her legal guardian blood sampling. This study was approved by the ethical committee (CCPPRB of Pitié-Salpêtrière Hospital, Paris, n69-03, 25/9/2003). 


\section{SCN1A, SCN8A and SCN9A analyses}

SCN1A was screened by direct sequencing and MLPA (multiplex ligation-dependent probe amplification) as previously described [10]. Mutations found in DS patients were searched for by direct sequencing of the corresponding exon in both parents; in the case of de novo mutations, seven highly polymorphic microsatellite markers (AFMa081we1, D2S2157, D2S124, D2S2363, D2S1395, D2S1379, AFMb362wd1) were used to confirm the pedigree structure. Four of these microsatellite markers at the 2q24.3 (SCN1A/SCN9A) locus (AFMa081we1, D2S124, D2S1395, and AFMb362wd1) and two microsatellite markers at the 12q13.13 (SCN8A) locus (D12S1629 and D12S1651) were genotyped in family members to establish haplotypes and follow segregation of the corresponding alleles in the families. PCR products mixed with the GENESCANTM 400HD ROX standard (Applied Biosystems) were run on an ABI 3730 automated sequencer (Applied Biosystems). Genotypes were analyzed with GeneMapper 3.5 software (Applied Biosystems).

\section{Quantitative allele-specific PCR}

Principle and experimental conditions for the allele-specific real time PCR assays, derived from the mismatch amplification mutation assay (TaqMAMA) were previously described [35]. Primer pairs specific for the mutations found in families 1-12, 14 and 15 were designed using PrimerExpress 1.5 (primer sequences are available on request). Specific and quantitative amplification using at least one primer pair was ensured using serial dilutions of DNA from the DS patient of each family in DNA from a control individual in which $75 \%, 50 \%, 25 \%$, or $12.5 \%$ of the DNA is from the patient. All real-time PCR experiments were performed using 100 ng of genomic DNA, $0.4 \mu \mathrm{M}$ of each primer and $12.5 \mu \mathrm{l}$ of Sybr Green PCR master mix (Applied Biosystems) in a total volume of $25 \mu$ l. The RNAse P (RNAse P control assay from Applied Biosystems) was used as the reference amplicon. Each sample was run in triplicate on an ABI PRISM 7700 Detection system (Applied Biosystems) and three different experiments were used for final quantification. Relative ratios were calculated using the formula $r=2^{-\Delta \Delta C t}$ with $\Delta \Delta \mathrm{Ct}=\left(\mathrm{Ct}_{\text {Mutation }}-\mathrm{Ct}_{\mathrm{RNAseP}}\right)$ ind tested $-\left(\mathrm{Ct}_{\text {Mutation }}-\mathrm{Ct}_{\mathrm{RNAseP}}\right)$ ind ref 


\section{Results}

Since 2003, we have screened a large series of 421 unrelated patients with DS for mutations in SCN1A (333 patients were previously reported [10]). At the time of this study, 319 patients (75\%) had a mutation in SCN1A. Analysis of both parents was possible for 177 patients and the mutation was de novo in 159/177 cases (89\%). In the 19 remaining cases, the mutation was inherited from one parent (Figure1, Table 1A). Inherited mutations included 4 nonsense mutations (p.Arg542X, p.Arg712X, p.Arg1912X and p.Arg580X), 3 mutations altering the splice sites (c.1377+1 G>A, c.602+1 G>A and c.965-2 A>C), 2 exonic deletions of one base pair (c.3878delA and c.5493delT), one whole gene deletion and 9 missense mutations (p.Ile124Asn, p.Asn191Tyr, p.Ile1782Met, p.Thr875Lys, p.Asn1367Lys, p.Leu1514Ser, p.Arg1648His, p.Thr1658Met and p.Met1664Lys). All mutations were absent from 180 Caucasian healthy controls.

The mutations were detectable in DNA extracted from the blood cells of the parent using direct sequencing in 15/19 cases. However, the amount of the mutated allele in the transmitting parent appeared lower than that of the affected child in 9 cases (families 1-9, Suppl. Figure1A), suggesting somatic mosaicism. In 3 families, the mutation was undetectable using direct sequencing in both parents but had been transmitted to two affected siblings (families 10-12), indicating germinal mosaicism. Finally, only the mother was available for genetic analysis in family 13 (whole gene deletion in two brothers) but she did not have the deletion.

Mosaicism in the parent of families 1-12 was confirmed using quantitative allele-specific real-time assays (Table 1A). The proportion of each mutation in the blood cells varied from $85 \%$ (family 1) to $0.04 \%$ (family 12). Although the mutation could not be detected using standard methods in families 10-12, the allele-specific assays allowed a specific amplification of the mutation from blood cells’ DNA of the parent in all three cases. In family 12, the quantity of mutation detected was very low but significant positive results were obtained for the mother $(0.0392 \pm 0.00643)$ compared to the father $(0.00677 \pm 0.00070$, equivalent to that found in control individuals), indicating that the mutation was present at a very low level 
in the blood cells of the mother. Likewise, in family 11, the allele-specific assay previously allowed a specific amplification from the blood cells' DNA of the father although direct sequencing failed to reveal the mutation [35]. The amount of mutation was previously estimated to $6 \%$ in the blood but we showed that the mutation was present at a higher proportion in the sperm $(24 \% \pm 11$, not shown). Together, these results confirmed that the transmitting parents carried the mutation at the mosaic state in their blood cells and/or in their germ cells in the 12 families (1-12). The mutation was inherited from the mother in 6 cases and from the father in the 6 others. Analysis of microsatellite markers in the SCN1A gene revealed that the whole gene deletion in family 13 originated from the father allele who was unavailable for genetic analyses (Suppl. Figure 2A). He was reported unaffected and mosaicism was therefore hypothesized in this family.

Contrary to families 1-12, the amount of the mutated allele in families 14-19 was identical in DS patients and their transmitting parent (Suppl. Figure 1B). In these 6 families, mutations were all of missense type and family histories were suggestive of autosomal dominant GEFS+ condition. In 2 families (16 and 19), the Leu1514Ser and Met1664Lys mutations were inherited over three or more generations, excluding the possibility of mosaicism in the transmitting parent (Figure 1B and Suppl. Figure 1B). In family 18, the Thr1658Met mutation was inherited from the asymptomatic mother who had affected brother and sister, suggesting that this mutation was also inherited over three generations, although none of them were available for genetic analyses. The Arg1648His mutation (family 17), was previously reported to cause GEFS+ in a large family [7]. The Thr875Lys mutation (family 14) affects the same amino-acid than the Thr875Met mutation described in another GEFS+ family [7] and was associated with a mild epilepsy in the sister's proband. In families 14 and 15, however, the mutation arose de novo in the transmitting fathers. The paternal grand-parents did not have the Thr875Lys mutation in family 14 (Suppl. Figure 1B). In family 15, analysis of microsatellite markers at the SCN1A locus revealed that the same haplotype was present with the Asn1367Lys mutation in the affected father and his daughter with DS, and without the mutation in his two healthy sisters (Suppl. Figure 1B and 2B). These results indicate that the mutation 
occurred de novo in the father or in one of his unavailable parents (Suppl. Figure 2B). We used allelespecific PCR assays to quantify the mutation in the blood of the fathers in these 2 families. The amount of mutated allele was similar in the fathers and in their affected children (not shown), supporting the hypothesis that this mutation was associated with GEFS+ phenotypes although somatic mosaicism in other tissues could not be totally excluded.

Interestingly, the mosaic parent had had seizures in 6 families (1, 2, 5, 7, 8 and 9, Supp. Table 2). In family 1 , the father had febrile seizures before age six and presented since early childhood with afebrile generalized tonic seizures and frequent myoclonic jerks. His epilepsy was less active when treated with AEDs but he was still on therapy at age 52. He presented with a slight mental delay and had scholar difficulties since the first elementary years. In family 2, the father also presented with a few febrile seizures before age 6 and had a unique generalized tonic-clonic seizure at age 25 . However, he had a good social insertion and normal cognitive abilities. In family 5, the mother was reported to have seizures since adolescence and was treated by carbamazepin and vigabatrin. Seizures were reported as focal temporal and GTC. She had a suspicion of left hippocampal sclerosis on MRI at age 28 and she was on waiting list for presurgical evaluation. She had a slight mental delay and a difficult social insertion, also due to her frequent seizures and for behavioural disturbances. The father of family 7 was intoxicated with carbon monoxide during infancy. He developed some GTCS during his childhood that stopped at the adolescence period. He was free of seizures without medication since this period. In family 8, the mother had seizures from the age of 11 months that remained untreated. She had no seizures between age 8 and 20 years. At the age of 20, seizures resumed and she was treated by phenobarbital. Treatment cessation led to the recurrence of the epilepsy. When seen at the age of 53, she was treated with sodium valproate and lamotrigine. In family 9, the father had no history of febrile seizures. He developed focal seizures at the age of 27, after a head trauma, but was free of seizures since he was treated with carbamazepine. It was therefore unclear whether the mutation was related to the development of seizures in this patient. If we exclude this latter case, the five affected mosaic parents have relatively high amounts of mutation in 
their blood cells (85\%; 65\%, 50\%, 45\% and 43\% respectively). Furthermore, the higher the amount of mutation was, the more severely the parent was affected. In contrast, mosaic parents of families $10-12$, with the lowest amounts of mutations (18 to $0.04 \%$ ) were all asymptomatic.

In contrast to their mosaic parent, all mutated children but one had classical DS. In 6 families, the mutation was present in two siblings and the clinical features of both children were remarkably similar with the exception of family 12. However, some discrepancies were observed, regarding for example the age at onset, occurrence of myoclonic jerks and status epilepticus. Strikingly, in family 12, the brother of the proband had the same mutation than his sister with DS (Arg1580X) but did not have DS: he had prolonged febrile seizures between age 1 and age 2 but had been free of seizures without medication afterwards until age 14. At the age of 14 , he developed afebrile generalized tonic-clonic seizures. Interestingly, this patient and his sister were genoidentical at the SCN1A locus (Suppl. Figure 3), indicating that the differences in phenotypes were not due to variants on the remaining normal SCN1A allele.

Two genes, SCN8A and SCN9A encoding neuronal voltage-gated sodium channels paralogous to SCN1A, have been reported to be modifiers of DS [38, 39]. To investigate whether these genes could be responsible for the clinical differences observed in families 12, 14, 17 and 18, in which sib pairs were discordant, we genotyped 6 microsatellite markers at the SCN1A/SCN9A (2q24) and SCN8A (12q13) loci. In family 12, neither SCN9A (located near SCN1A) nor SCN8A could explain the moderate phenotype in the brother of the proband since they share the same genotypes at both loci. Likewise, in family 18, at least two discordant patients share the same genotype for each locus (Suppl. Figure 3). These results indicated that SCN8A and SCN9A were not the modifier genes, at least in these families. 


\section{Discussion}

In this study, we have shown that mosaicism is the main event associated with inherited SCN1A mutations in DS patients (68\%, 13/19 families). Parental mosaicism in DS is not a rare situation since it was found in at least 7\% (13/177) of the families with a SCN1A mutation in our cohort [10]. When the level of somatic mosaicism is high, the parent can present with seizures, although he is less severely affected than his child who carry the mutation in all his cells. Nevertheless, mosaicism is not the only situation accounting for inherited mutations as DS can also be encountered in the context of GEFS+ families. In that case, SCN1A missense mutations segregating in the family are associated with a wide phenotypic variability, with DS at the severe end of the spectrum. Inherited mutations introducing a premature termination codon (i.e. nonsense, spice site mutations, mutations introducing frameshifts) were always associated with somatic mosaicism. It was thus hypothesized that the two brothers in family 13 had inherited the gene deletion from a mosaic father. On the contrary, the example of families 14 and 15 illustrates that it can be difficult to make a clear distinction between these two situations when confronted to missense mutations without clear evidence of mosaicism or GEFS+ context. Distinguishing mosaicism from de novo constitutional mutations or other situations is of particular concern in disorders that are frequently sporadic, such as DS, in order to give appropriate genetic counseling [40].

DS patients with inherited SCN1A mutations were periodically reported in the literature: the corresponding data are summarized in Suppl. Table 3. Mosaicism has been reported in 8 other independent families in which a point mutation or an intragenic rearrangement of SCN1A was identified [14, 34, 36, 37, 41]. One additional case (Glu289X, inherited from the mother) was also probably due to mosaicism although this was not demonstrated [29]. Only one DS patient with an identified SCN1A mutation (Met1841Thr) within a large GEFS+ family [23] was reported. In all other patients (who all had missense mutations), parents were not tested or mosaicism was not ascertained [29, 30, 33, 42].

Somatic mosaicism was suspected in the families reported in this study since the amount of mutation in the parent appeared lower than that of his child with DS. In 3 families, however, the mutation could not be 
detected by direct sequencing since its amount was less than 20\% in DNA from blood cells. In these cases, the recurrent transmission of the mutation to another affected child prompted us to search for mosaicism. In absence of a second affected child, mosaicism in these families would have been missed. If we admit that the recurrent transmission of the mutation is weakly probable when mosaicism is low, then it is very likely that mosaicism could be more frequent than $7 \%$. The risk of recurrence is, therefore, not null when the mutation is apparently de novo, which should be taken into account for genetic counseling. Somatic mosaicism could even turn out to be more frequent as originally suspected. Here, we have detected only mosaic parents who have transmitted the mutation to their offsprings. It is difficult to predict how many patients could have a SCN1A mutation at the somatic mosaic state without transmitting it. One could hypothesize that somatic mosaicism of SCN1A - or other genes - affecting the brain is one cause accounting for isolated patients with idiopathic epilepsies or febrile seizures.

In this study, quantitative allele-specific amplification of the mutation in the blood of the mosaic parent revealed that the amount of the mutation was very variable for one parent to another (from 0 to $85 \%$ ). The clinical status of the mosaic parent appeared somehow correlated with the amount of the mutation in his blood cells although this correlation is not strict. Indeed, the transmitting parents with the lowest percentages $(<30 \%$, families $10-12)$ of mutation were all unaffected. Three parents out of the 6 with a mutation rate close to $50 \%$ (families 3-8) were affected suggesting that in this case, the parent had a $50 \%$ risk of being affected. These observations suggest that the occurrence and severity of the epilepsy could be correlated with the amount of mutation in the brain of the parent although this hypothesis is difficult to demonstrate in absence of post-mortem tissues. Peripheral mosaicism does not always reflect the neuronal mosaicism as blood cells and neurons are not originated from the same embryonic stem cells. However, when the mutation occurs late during development, the probability that the mutation is present at a high rate in a tissue is weak. Conversely, when the mutation occurs very early in the development, the presence of the mutation in a tissue happens randomly or is dependent from negative selective pressure. If there is no selective pressure, and cells of the tissue originate from a population including many mutated cells, the 
amount of mutation could be very high in most tissues $[40,43]$. This would explain why we observed a partial correlation between the clinical status of the mosaic parent and the amount of mutation in his blood cells. Another interesting issue is that only specific neuron types could be sensitive to or affected by the mutation, as reported for the Arg1648His mutation [44]. In that case, the higher the amount of mutation is, the higher the probability that these neurons would express it.

At least 30 other genetic diseases showing variable expressivity have been linked to somatic mosaicism [40, 43]. Most of these diseases are severe and it is likely that somatic mosaicism is more frequent in disorders with an elevated rate of de novo mutations. However, although case reports of mosaicism are frequent in such disorders, the consequences of mosaicism and the correlation between the amount of mutation in concerned tissues and the clinical variability are rarely studied.

One question that remains is whether SCN1A neomutations (causing DS) act through the same pathophysiological mechanisms than mutations found in GEFS+. Both situations presented here give valuable insights regarding this issue. Basically, mutations associated with clear loss-of-function are almost always associated with DS and are never found in GEFS+. However, these mutations can be associated with milder phenotypes reminiscent of those seen in GEFS+ if present in only some neurons. Conversely, missense mutations found in GEFS+ are generally associated with mild epileptic phenotypes but can occasionally cause DS. From a mechanistic point of view, it is likely that the pathophysiological pathways are different: de novo mutations would be sufficient to cause DS whereas missense mutations associated with GEFS+ would not and additional genetic or non-genetic factors would be necessary to cause DS in the latter case. A recent study provides an interesting hypothesis regarding factors that could influence the disorder: mutations identified in GEFS + families would result in folding-defective proteins which function could be partially rescued by interactions with associated proteins and drugs. In this context, severe phenotypes such as DS could emerge within a permissive genetic background [22, 45]. The example of family 12 shows that the limits between DS and GEFS+ are even more blurred that patients with truncating mutations could also present with milder phenotypes. In both cases, yet unidentified 
factors obviously influence the course and outcome of the disease. Parental mosaicism having main consequences in terms of genetic counseling, it is thus important to recognize it when possible. A prenatal diagnosis should be achievable once the pathogenicity of the mutation has been determined. 


\section{Acknowledgements}

The authors thank the families for their participation in this study and the bank of IFR70 for DNA extraction of some families. We thank Fernand Coriat, Brigitte Gilbert's lab members and and Dr Archambeau (CECOS, Nîmes) for their participation in collecting parents or sperm samples. This work was financially supported by the Programme Hospitalier de Recherche Clinique AP-HP (nP020910/AOR02085) and INSERM.

Competing Interest: None to declare.

The Corresponding Author has the right to grant on behalf of all authors and does grant on behalf of all authors, an exclusive licence (or non exclusive for government employees) on a worldwide basis to the BMJ Publishing Group Ltd and its Licensees to permit this article (if accepted) to be published in JMG editions and any other BMJPGL products to exploit all subsidiary rights, as set out in our licence(http://group.bmj.com/products/journals/instructions-for-authors/licence-forms/). 


\section{References}

1 Dravet C, Bureau M, Oguni H, et al. Severe myoclonic epilepsy in infancy: Dravet syndrome. AdvNeurol 2005;95:71-102.

2 Ohmori I, Ouchida M, Ohtsuka Y, et al. Significant correlation of the SCN1A mutations and severe myoclonic epilepsy in infancy. Biochem Biophys Res Commun 2002;295(1):17-23.

3 Scheffer IE, Berkovic SF. Generalized epilepsy with febrile seizures plus. A genetic disorder with heterogeneous clinical phenotypes. Brain 1997;120 ( Pt 3):479-90.

4 Singh R, Scheffer IE, Crossland K, et al. Generalized epilepsy with febrile seizures plus: a common childhood-onset genetic epilepsy syndrome. Ann Neurol 1999;45(1):75-81.

5 Baulac S, Gourfinkel-An I, Picard F, et al. A second locus for familial generalized epilepsy with febrile seizures plus maps to chromosome 2q21-q33. AmJHumGenet 1999;65(4):1078-85.

6 Ito $\mathrm{M}$, Nagafuji $\mathrm{H}$, Okazawa $\mathrm{H}$, et al. Autosomal dominant epilepsy with febrile seizures plus with missense mutations of the $(\mathrm{Na}+)$-channel alpha 1 subunit gene, SCN1A. Epilepsy Res 2002;48(1-2):15-23.

7 Escayg A, MacDonald BT, Meisler MH, et al. Mutations of SCN1A, encoding a neuronal sodium channel, in two families with GEFS+2. NatGenet 2000;24(4):343-5.

8 Claes L, Del-Favero J, Ceulemans B, et al. De novo mutations in the sodium-channel gene SCN1A cause severe myoclonic epilepsy of infancy. Am J Hum Genet 2001;68(6):1327-32.

9 Claes L, Ceulemans B, Audenaert D, et al. De novo SCN1A mutations are a major cause of severe myoclonic epilepsy of infancy. Hum Mutat 2003;21(6):615-21.

10 Depienne C, Trouillard O, Saint-Martin C, et al. Spectrum of SCN1A gene mutations associated with Dravet syndrome: analysis of 333 patients. J Med Genet 2009;46(3):183-91.

11 Mulley JC, Scheffer IE, Petrou S, et al. SCN1A mutations and epilepsy. HumMutat 2005;25(6):535-42.

12 Suls A, Claeys KG, Goossens D, et al. Microdeletions involving the SCN1A gene may be common in SCN1A-mutation-negative SMEI patients. Hum Mutat 2006;27(9):914-20.

13 Madia F, Striano P, Gennaro E, et al. Cryptic chromosome deletions involving SCN1A in severe myoclonic epilepsy of infancy. Neurology 2006;67(7):1230-5.

14 Marini C, Scheffer IE, Nabbout R, et al. SCN1A duplications and deletions detected in Dravet syndrome: Implications for molecular diagnosis. Epilepsia 2009.

15 Fujiwara T. Clinical spectrum of mutations in SCN1A gene: severe myoclonic epilepsy in infancy and related epilepsies. Epilepsy Res 2006;70 Suppl 1:S223-30.

16 Ohmori I, Kahlig KM, Rhodes TH, et al. Nonfunctional SCN1A is common in severe myoclonic epilepsy of infancy. Epilepsia 2006;47(10):1636-42.

17 Burgess DL. Neonatal epilepsy syndromes and GEFS+: mechanistic considerations. Epilepsia 2005;46 Suppl 10:51-8.

18 Rhodes TH, Vanoye CG, Ohmori I, et al. Sodium Channel Dysfunction in Intractable Childhood Epilepsy with Generalized Tonic-Clonic Seizures. JPhysiol 2005.

19 Lossin C, Rhodes TH, Desai RR, et al. Epilepsy-associated dysfunction in the voltage-gated neuronal sodium channel SCN1A. JNeurosci 2003;23(36):11289-95.

20 Vanoye CG, Lossin C, Rhodes TH, et al. Single-channel properties of human NaV1.1 and mechanism of channel dysfunction in SCN1A-associated epilepsy. $J$ Gen Physiol 2006;127(1):1-14.

21 Rhodes TH, Lossin C, Vanoye CG, et al. Noninactivating voltage-gated sodium channels in severe myoclonic epilepsy of infancy. ProcNatlAcadSciUSA 2004;101(30):11147-52.

22 Rusconi R, Combi R, Cestele S, et al. A rescuable folding defective Nav1.1 (SCN1A) sodium channel mutant causes GEFS+: common mechanism in Nav1.1 related epilepsies? Hum Mutat 2009;30(7):E747-60. 
23 Annesi G, Gambardella A, Carrideo S, et al. Two novel SCN1A missense mutations in generalized epilepsy with febrile seizures plus. Epilepsia 2003;44(9):1257-8.

24 Veggiotti P, Cardinali S, Montalenti E, et al. Generalized epilepsy with febrile seizures plus and severe myoclonic epilepsy in infancy: a case report of two Italian families. EpilepticDisord 2001;3(1):29-32.

25 Scheffer IE, Wallace R, Mulley JC, et al. Clinical and molecular genetics of myoclonic-astatic epilepsy and severe myoclonic epilepsy in infancy (Dravet syndrome). Brain Dev 2001;23(7):732-5.

26 Wallace RH, Hodgson BL, Grinton BE, et al. Sodium channel alpha1-subunit mutations in severe myoclonic epilepsy of infancy and infantile spasms. Neurology 2003;61(6):765-9.

27 Fujiwara T, Sugawara T, Mazaki-Miyazaki E, et al. Mutations of sodium channel alpha subunit type 1 (SCN1A) in intractable childhood epilepsies with frequent generalized tonic-clonic seizures. Brain 2003;126(Pt 3):531-46.

28 Singh R, Andermann E, Whitehouse WP, et al. Severe myoclonic epilepsy of infancy: extended spectrum of GEFS+? Epilepsia 2001;42(7):837-44.

29 Nabbout R, Gennaro E, Dalla Bernardina B, et al. Spectrum of SCN1A mutations in severe myoclonic epilepsy of infancy. Neurology 2003;60(12):1961-7.

30 Kimura K, Sugawara T, Mazaki-Miyazaki E, et al. A missense mutation in SCN1A in brothers with severe myoclonic epilepsy in infancy (SMEI) inherited from a father with febrile seizures. Brain Dev 2005;27(6):424-30.

31 Gennaro E, Veggiotti P, Malacarne M, et al. Familial severe myoclonic epilepsy of infancy: truncation of Nav1.1 and genetic heterogeneity. EpilepticDisord 2003;5(1):21-5.

32 Mancardi MM, Striano P, Gennaro E, et al. Familial occurrence of febrile seizures and epilepsy in severe myoclonic epilepsy of infancy (SMEI) patients with SCN1A mutations. Epilepsia 2006;47(10):1629-35.

33 Fukuma G, Oguni H, Shirasaka Y, et al. Mutations of neuronal voltage-gated $\mathrm{Na}+$ channel alpha 1 subunit gene SCN1A in core severe myoclonic epilepsy in infancy (SMEI) and in borderline SMEI (SMEB). Epilepsia 2004;45(2):140-8.

34 Gennaro E, Santorelli FM, Bertini E, et al. Somatic and germline mosaicisms in Severe Myoclonic Epilepsy of Infancy. BiochemBiophysResCommun 2006;341(2):489-93.

35 Depienne C, Arzimanoglou A, Trouillard O, et al. Parental mosaicism can cause recurrent transmission of SCN1A mutations associated with severe myoclonic epilepsy of infancy. Hum Mutat 2006;27(4):389.

36 Morimoto M, Mazaki E, Nishimura A, et al. SCN1A mutation mosaicism in a family with severe myoclonic epilepsy in infancy. Epilepsia 2006;47(10):1732-6.

37 Marini C, Mei D, Helen Cross J, et al. Mosaic SCN1A mutation in familial severe myoclonic epilepsy of infancy. Epilepsia 2006;47(10):1737-40.

38 Singh NA, Pappas C, Dahle EJ, et al. A role of SCN9A in human epilepsies, as a cause of febrile seizures and as a potential modifier of Dravet syndrome. PLoS Genet 2009;5(9):e1000649.

39 Martin MS, Tang B, Papale LA, et al. The voltage-gated sodium channel Scn8a is a genetic modifier of severe myoclonic epilepsy of infancy. Hum Mol Genet 2007;16(23):2892-9.

40 Youssoufian H, Pyeritz RE. Mechanisms and consequences of somatic mosaicism in humans. NatRevGenet 2002;3(10):748-58.

41 Selmer KK, Eriksson AS, Brandal K, et al. Parental SCN1A mutation mosaicism in familial Dravet syndrome. Clin Genet 2009;76(4):398-403.

42 Harkin LA, McMahon JM, Iona X, et al. The spectrum of SCN1A-related infantile epileptic encephalopathies. Brain 2007;130(Pt 3):843-52.

43 Gottlieb B, Beitel LK, Trifiro MA. Somatic mosaicism and variable expressivity. Trends Genet 2001;17(2):79-82. 
44 Tang B, Dutt K, Papale L, et al. A BAC transgenic mouse model reveals neuron subtypespecific effects of a Generalized Epilepsy with Febrile Seizures Plus (GEFS+) mutation. Neurobiol Dis 2009;35(1):91-102.

45 Rusconi R, Scalmani P, Cassulini RR, et al. Modulatory proteins can rescue a trafficking defective epileptogenic Nav1.1 Na+ channel mutant. J Neurosci 2007;27(41):11037-46. 


\section{FIGURE LEGENDS}

Figure 1. Pedigrees and segregation analysis of the SCN1A mutations in families 1-19. A) Families 113: Mutations found in DS patients were inherited from a mosaic asymptomatic or mildly affected parent; B) Families 14-19: Missense mutations found in DS patients segregated in families with autosomal dominant generalized epilepsy with febrile seizures plus (GEFS+) and were associated with variable expressivity. The arrow indicates the index case. Black symbols correspond to patients with Dravet syndrome (DS). Grey symbols represent patients with idiopathic generalized epilepsy (IGE). Right upper black squares indicate patients who had febrile seizures. Symbol with crosswise hatching stands for a patient with symptomatic epilepsy after head trauma. 


\section{Figure 1A}

Family 1

$\mathrm{m}=\mathrm{c} .1377+1 \mathrm{G}>\mathrm{A}$

(intron 9)

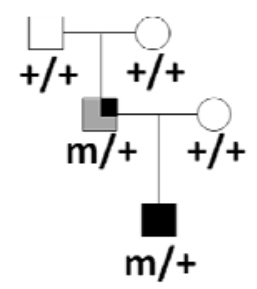

Family 2

$\mathrm{m}=\mathrm{c} .3878$ delA

(exon 19)

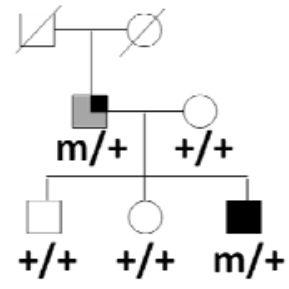

Family 3
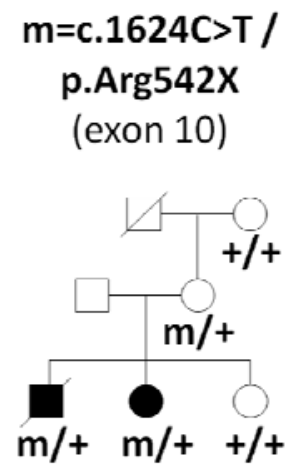

Family 4

$m=c .602+1 G>A$

(intron 4)

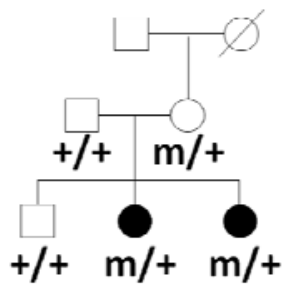

\begin{tabular}{|c|c|c|c|c|}
\hline Family 5 & Family 6 & Family 7 & Family 8 & Family 9 \\
\hline $\begin{array}{c}n=c .371 T>A / \\
\text { p.lle124Asn } \\
(\text { exon 2) }\end{array}$ & $\begin{array}{c}\mathrm{m}=\mathrm{c.2134C}>\mathrm{T} / \\
\text { p.Arg712X } \\
(\text { exon } 12)\end{array}$ & $\begin{array}{c}\mathrm{m}=\mathbf{c . 5 7 1 A}>\mathrm{T} / \\
\text { p.Asn191Tyr } \\
(\text { exon 4) }\end{array}$ & $\begin{array}{c}\mathbf{m}=\mathbf{c . 5 4 9 3 d e l T} \\
(\text { exon 26) }\end{array}$ & $\begin{array}{c}\mathrm{m}=\mathrm{c} .5346 \mathrm{C}>\mathrm{G} / \\
\text { p.lle1782Met } \\
(\text { exon 26) }\end{array}$ \\
\hline$+/+\mathrm{m} /+$ & $\mathrm{m} /+$ & $\mathrm{m} /++\mathrm{t}+$ & $\mathrm{m} /+$ & \begin{tabular}{c|c}
$7 / 1$ \\
$\mathrm{~m} /+$
\end{tabular}$+\mathrm{+}$ \\
\hline
\end{tabular}

Family 10

$\mathrm{m}=\mathrm{c} .5734 \mathrm{C}>\mathrm{T} /$

p.Arg1912X

(exon 26)

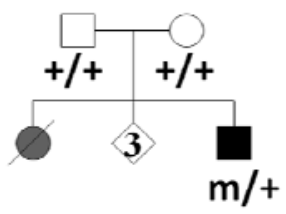

Family 11

$m=c .965-2 A>C$

(intron 6)

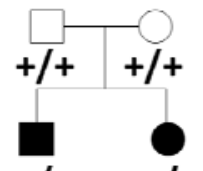

$\mathrm{m} /+\mathrm{m} /+$
Family 12

$\mathrm{m}=\mathrm{c} .1738 \mathrm{C}>\mathrm{T} /$

p.Arg580X

(exon 11)

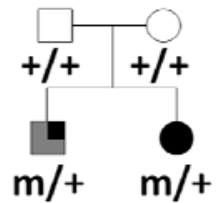

Family 13

$d=$ whole gene deletion

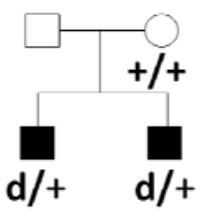




\section{Figure 1B}

Family 14

$$
\begin{gathered}
\mathrm{m}=\text { c.2624C }>\mathrm{A} / \\
\text { p.Thr875Lys } \\
\text { (exon 15) }
\end{gathered}
$$

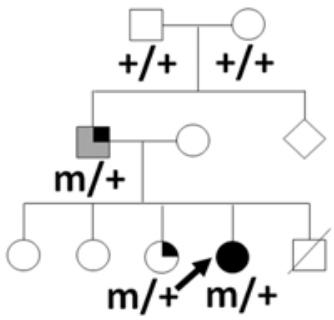

Family 16

$$
\begin{gathered}
\mathrm{m}=\mathrm{c} .4541 \mathrm{~T}>\mathrm{C} / \\
\text { p.Leu1514Ser }
\end{gathered}
$$$$
\text { (exon 24) }
$$

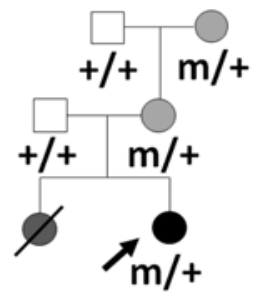

Family 18

$\mathrm{m}=\mathrm{c} .4973 \mathrm{C}>\mathrm{T} /$

p.Thr1658Met

(exon 26)

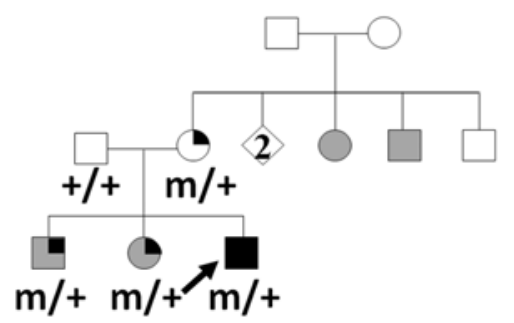

Family 15

$$
\begin{gathered}
\mathrm{m}=\text { c.4101T }>\mathrm{A} / \\
\text { p.Asn1367Lys } \\
(\text { exon 21) }
\end{gathered}
$$

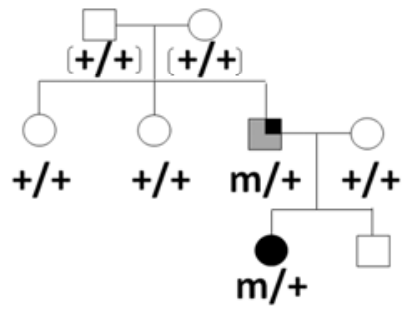

\section{Family 17}

$m=c .4943 G>A$ /

p.Arg1648His

(exon 26)

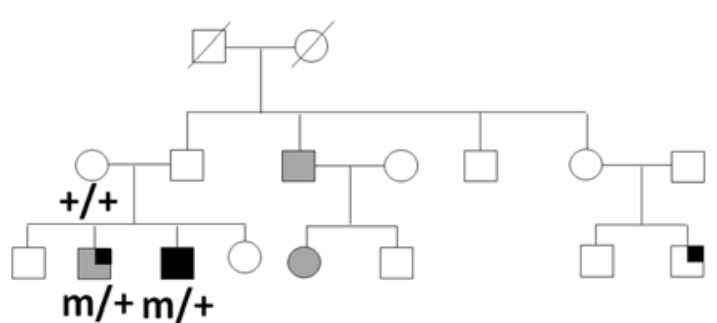

$\mathrm{m}=\mathrm{c} .4991 \mathrm{~T}>\mathrm{A} /$
p.Met1664Lys

(exon 26)

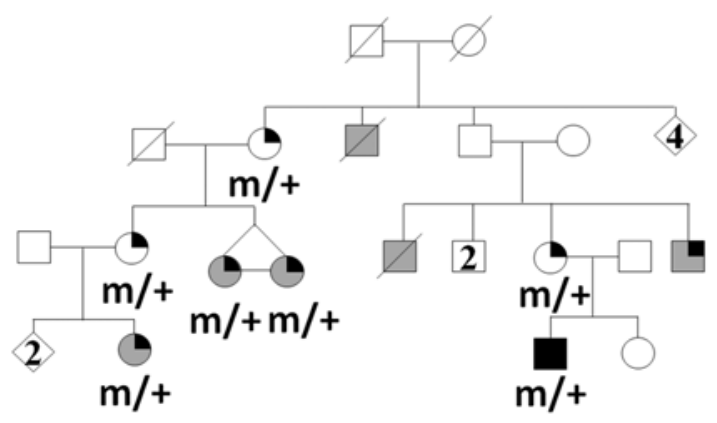


Table 1A: DS patients with a SCN1A mutation inherited by a mosaic parent

\begin{tabular}{|c|c|c|c|c|c|c|}
\hline Family & $\begin{array}{c}\text { Nb of } \\
\text { SMEI } \\
\text { children }\end{array}$ & $\begin{array}{l}\text { Mutation type } \\
\text { (Mutation) }\end{array}$ & $\begin{array}{l}\text { Transmission to } \\
\text { the SMEI child }\end{array}$ & $\begin{array}{l}\text { Clinical status of } \\
\text { transmitting } \\
\text { parent }\end{array}$ & $\begin{array}{l}\% \text { of mutated allele in parent's blood cells } \\
\text { (TaqMAMA quantification) }\end{array}$ & $\begin{array}{c}\text { Detection of the mutation in } \\
\text { parent's blood cells (direct } \\
\text { sequencing) }\end{array}$ \\
\hline 1 & 1 & $\begin{array}{c}\text { Truncating } \\
\text { (c.1378+1G>A) }\end{array}$ & Paternal & $\begin{array}{l}\text { Severely Affected } \\
\text { but not DS }\end{array}$ & $85.18 \pm 12$ & Yes \\
\hline 2 & 1 & $\begin{array}{l}\text { Truncating } \\
\text { (c.3878delA) }\end{array}$ & Paternal & Affected & $64.59 \pm 10$ & Yes \\
\hline 3 & 2 & $\begin{array}{l}\text { Truncating } \\
\text { (p.Arg542X) }\end{array}$ & Maternal & Unaffected & $54.04 \pm 4$ & Yes \\
\hline 4 & 2 & $\begin{array}{c}\text { Truncating } \\
(602+1 G>A)\end{array}$ & Maternal & Unaffected & $50.06 \pm 6$ & Yes \\
\hline 5 & 1 & $\begin{array}{c}\text { Missense } \\
\text { (p.Ile124Asn) }\end{array}$ & Maternal & $\begin{array}{l}\text { Severely Affected } \\
\text { but not DS }\end{array}$ & $49.77 \pm 5$ & Yes \\
\hline 6 & 1 & $\begin{array}{l}\text { Truncating } \\
\text { (p.Arg712X) }\end{array}$ & Maternal & Unaffected & $45.70 \pm 7$ & Yes \\
\hline 7 & 1 & $\begin{array}{l}\text { Missense } \\
\text { (p.Asn191Tyr) }\end{array}$ & Paternal & Affected & $45.33 \pm 8$ & Yes \\
\hline 8 & 1 & $\begin{array}{l}\text { Truncating } \\
\text { (c.5493delT) }\end{array}$ & Maternal & Affected & $43.05 \pm 7$ & Yes \\
\hline 9 & 1 & $\begin{array}{c}\text { Missense } \\
\text { (p.Ile1782Met) }\end{array}$ & Paternal & $\begin{array}{l}\text { Affected (seizures } \\
\text { after a head } \\
\text { trauma) }\end{array}$ & $33.63 \pm 5$ & Yes \\
\hline 10 & $\begin{array}{l}1 \text { (+ } 1 \text { child } \\
\text { prematurely } \\
\text { deceased })\end{array}$ & $\begin{array}{c}\text { Truncating } \\
\text { (p.Arg1912X) }\end{array}$ & Paternal & Unaffected & $17.52 \pm 1$ & No \\
\hline 11 & 2 & $\begin{array}{c}\text { Truncating } \\
(\text { c.965-2A>C) }\end{array}$ & Paternal & Unaffected & $6.05 \pm 2$ & No \\
\hline 12 & 1 & $\begin{array}{l}\text { Truncating } \\
\text { (p.Arg580X) }\end{array}$ & Maternal & Unaffected & $0.04 \pm 0.01$ & No \\
\hline 13 & 2 & $\begin{array}{l}\text { Whole gene } \\
\text { deletion }\end{array}$ & NA & Unaffected & NA & NA \\
\hline
\end{tabular}

NA: Not available; Nb: number

Table 1B: DS patients with a SCN1A mutation inherited in a GEFS+ familial context

\begin{tabular}{|c|c|c|c|c|}
\hline Family & Nb of SMEI children & Transmission to the SMEI child & Clinical status of transmitting parent & Mutation type \\
\hline
\end{tabular}




\begin{tabular}{|c|c|c|c|c|}
\hline 14 & 1 & Paternal (de novo in the father) & Affected & $\begin{array}{c}\text { Missense } \\
\text { (p.Thr875Lys) }\end{array}$ \\
\hline 15 & 1 & Paternal (de novo in the father) & Affected & $\begin{array}{c}\text { Missense } \\
\text { (p.Asn1367Lys) }\end{array}$ \\
\hline 16 & 1 & Maternal (Familial) & Affected & $\begin{array}{c}\text { Missense } \\
\text { (p.Leu1514Ser) }\end{array}$ \\
\hline 17 & 1 & $\begin{array}{l}\text { Paternal inheritance suspected } \\
\text { (Familial) }\end{array}$ & Unaffected & $\begin{array}{c}\text { Missense } \\
\text { (p.Arg1648His) }\end{array}$ \\
\hline 18 & 1 & Maternal (Familial) & Unaffected & $\begin{array}{c}\text { Missense } \\
\text { (p.Thr1658Met) }\end{array}$ \\
\hline 19 & 1 & Maternal (Familial) & FS & $\begin{array}{c}\text { Missense } \\
\text { (p.Met1664Lys) }\end{array}$ \\
\hline
\end{tabular}

NA: Not Available; Nb: number 


\section{Suppl. Figure 1A}

Family 1

$\mathrm{m}=\mathrm{c} .1377+1 \mathrm{G}>\mathrm{A}$

2 MMMONWM

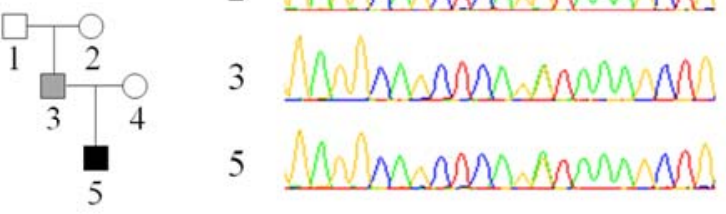

Family 2

$\mathrm{m}=\mathrm{c} .3878$ delA

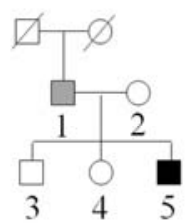

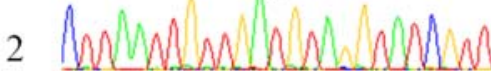

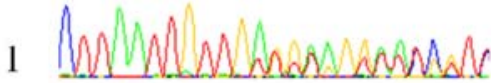

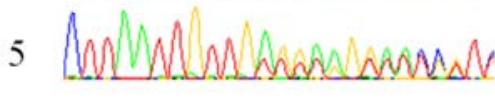

Family 3 $\mathrm{m}=\mathrm{c} .1624 \mathrm{C}>\mathrm{T} /$ p.Arg542X $\triangle D_{1}$

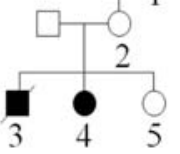

Family 5

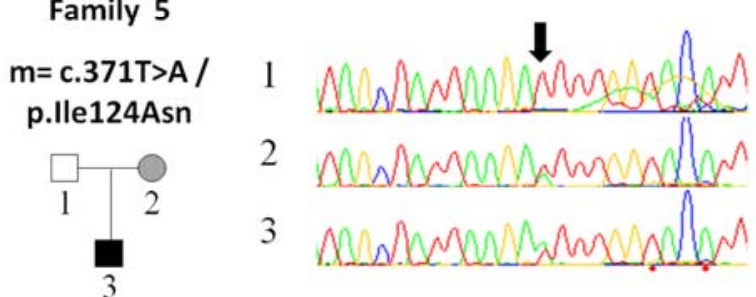

Family 7 $\mathrm{m}=\mathrm{c} .571 \mathrm{~A}>\mathrm{T} /$ p.Asn191Tyr

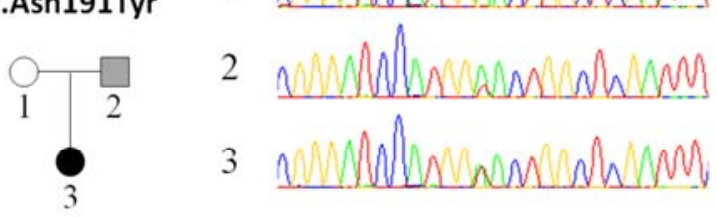

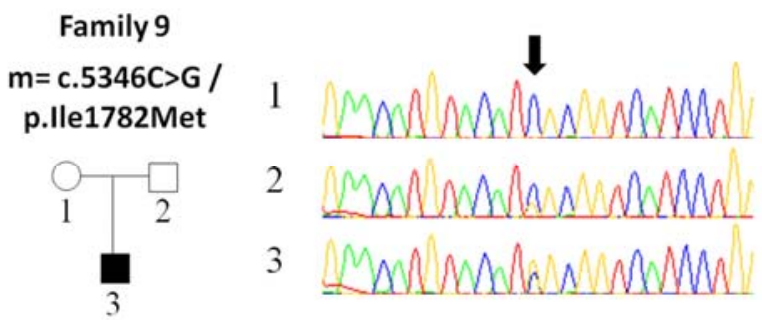

Family 11

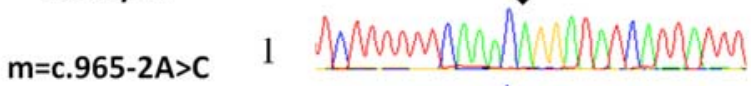

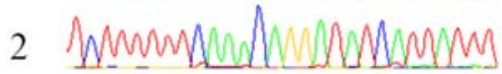

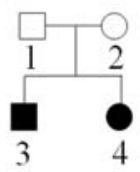

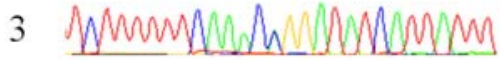

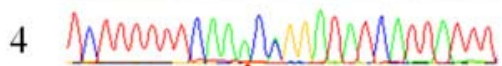

Family 4

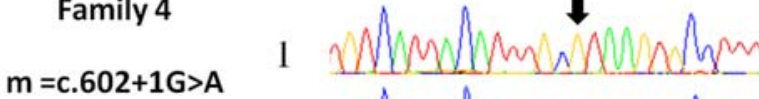

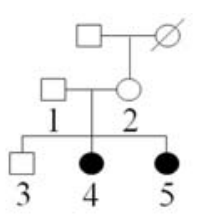

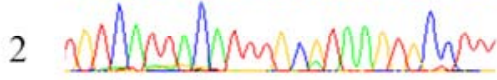

4 Mhendminoming

5 Mhondminominn

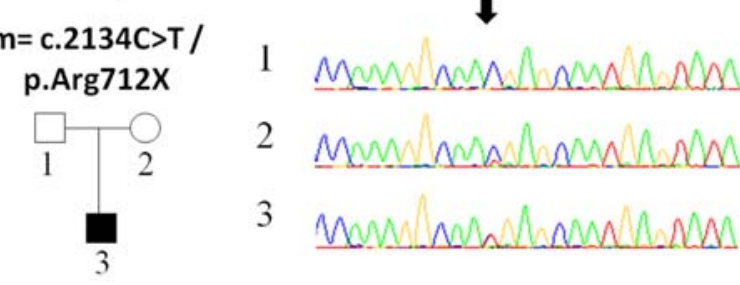

Family 8

$\mathrm{m}=\mathrm{c} .5493$ delT

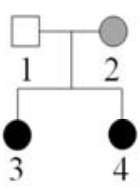

Family 10

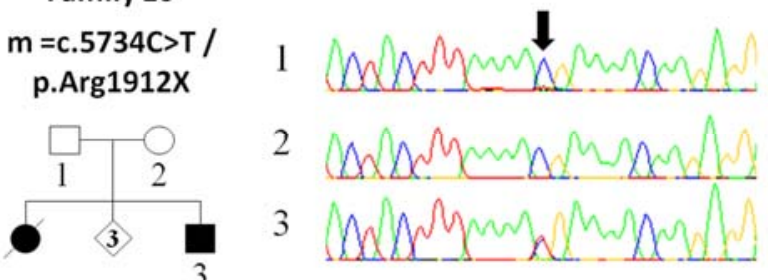

1 MEMM MU MMMM

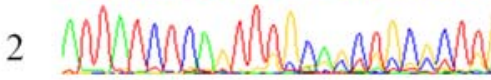

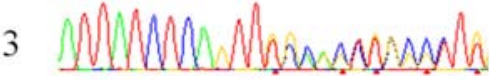

4 MWMm Mha manam
Family 12

$\mathrm{m}=\mathrm{c} .1738 \mathrm{C}>\mathrm{T} /$ p.Arg580X

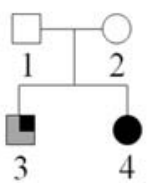




\section{Suppl. Figure 1B}
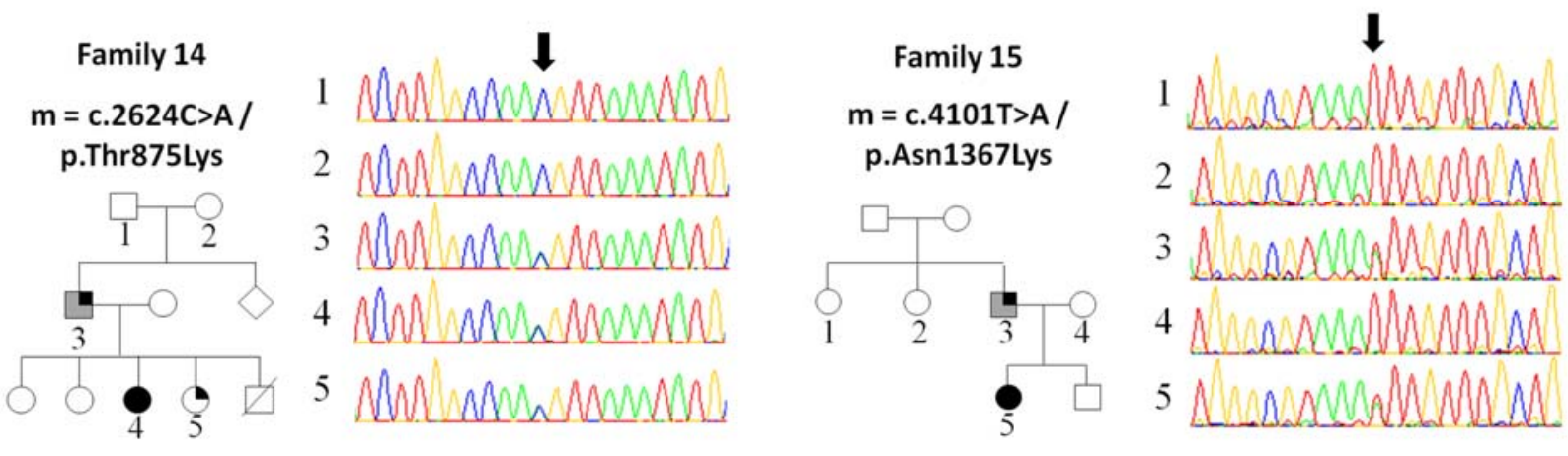

\section{Family 16}
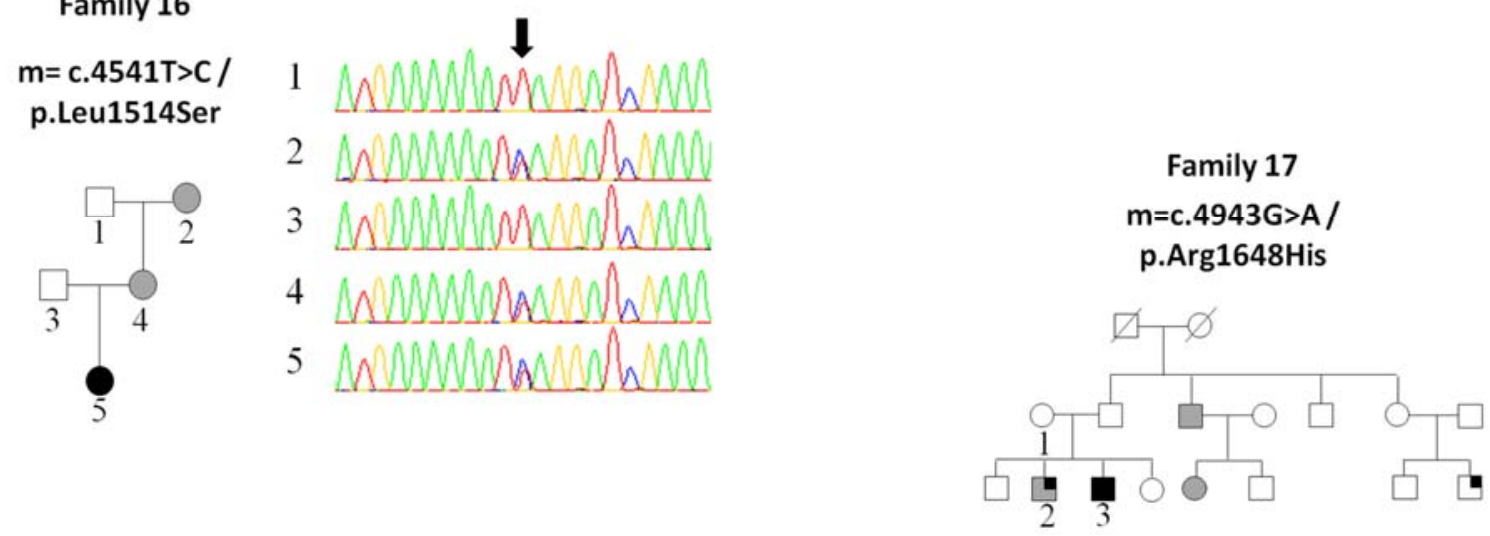

Family 18 $\mathrm{m}=\mathrm{c} .4973 \mathrm{C}>\mathrm{T} /$ p.Thr1658Met

Family 19
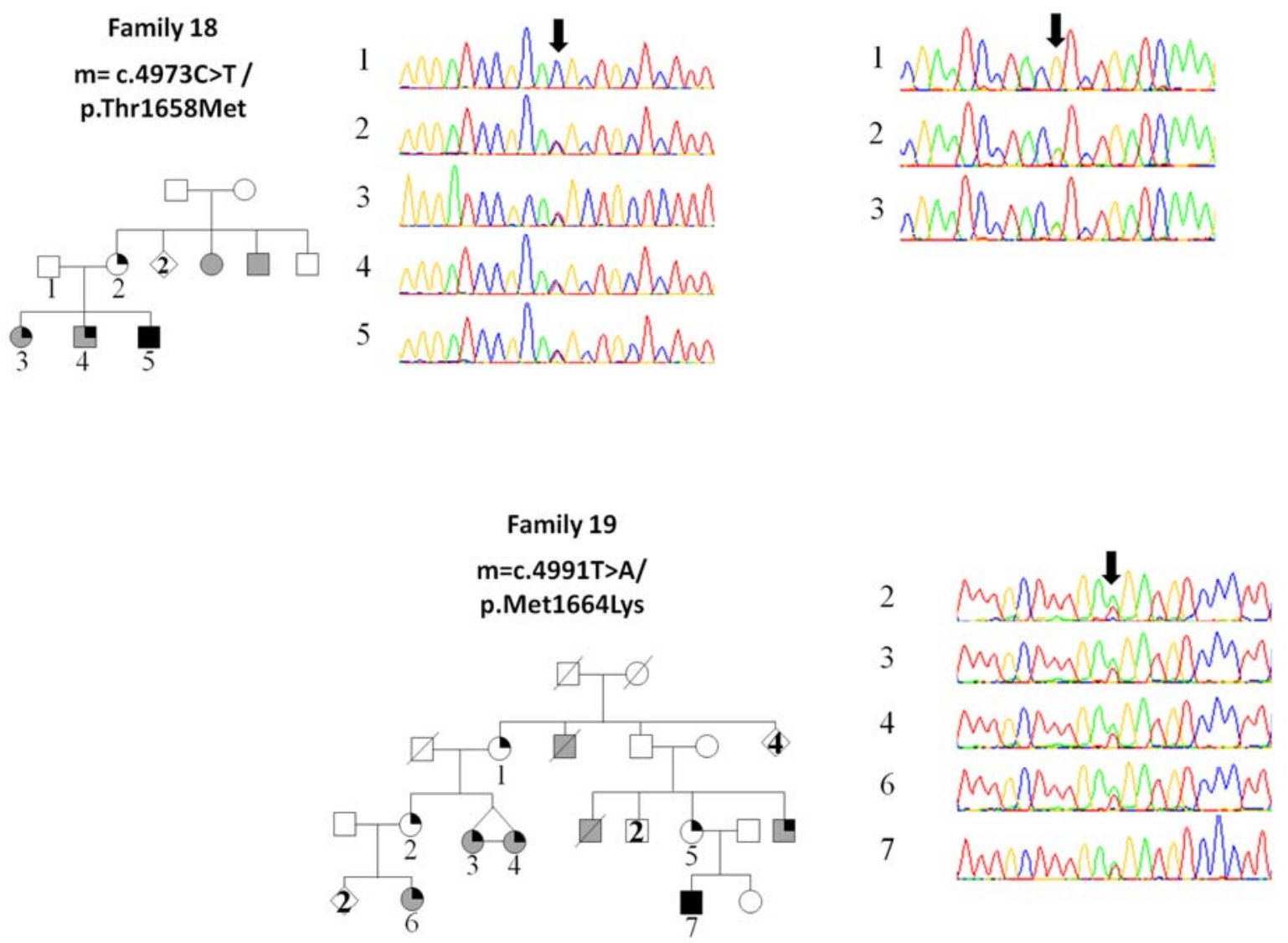


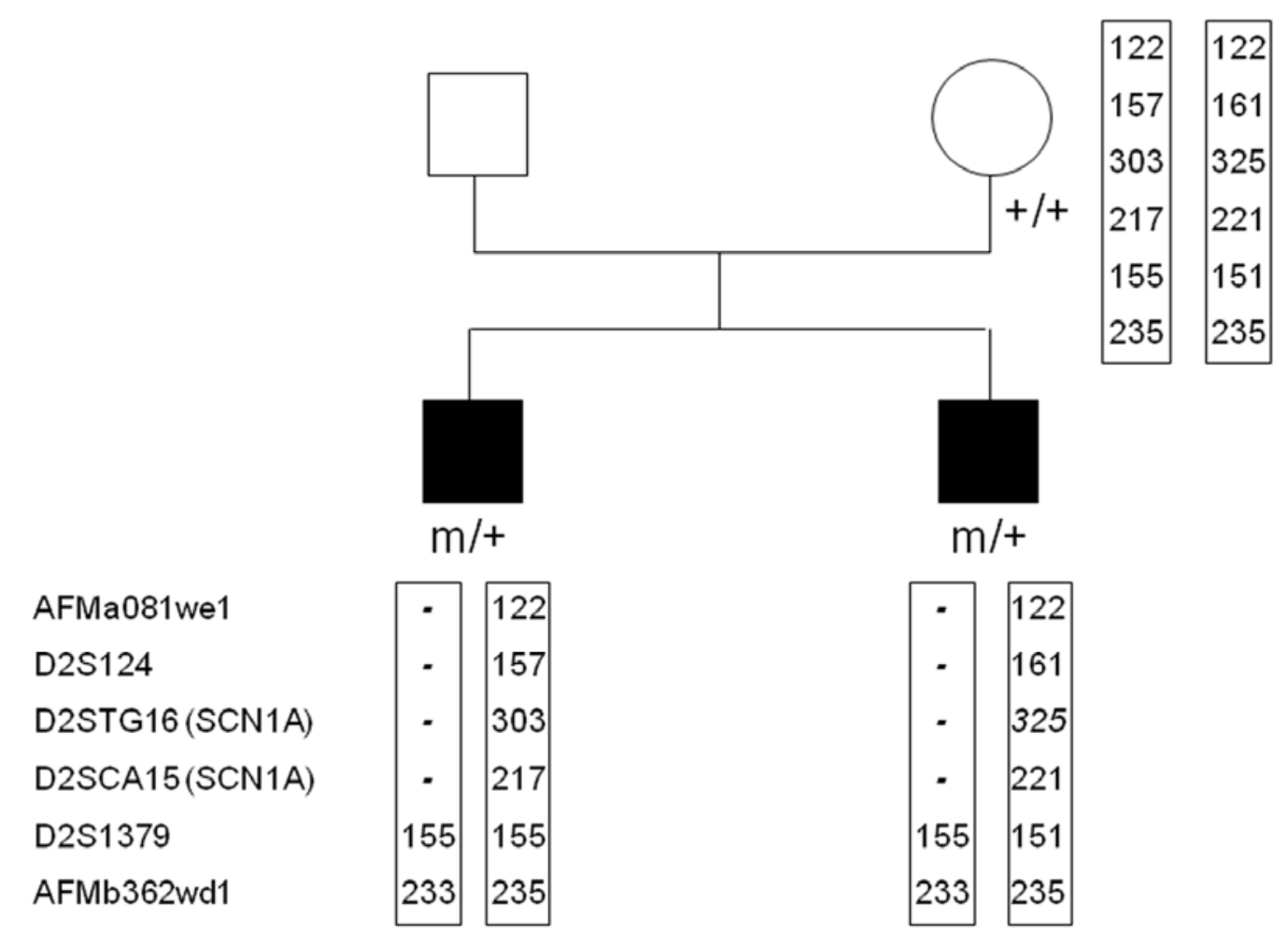




\section{Suppl. Figure 2B}

Family 15

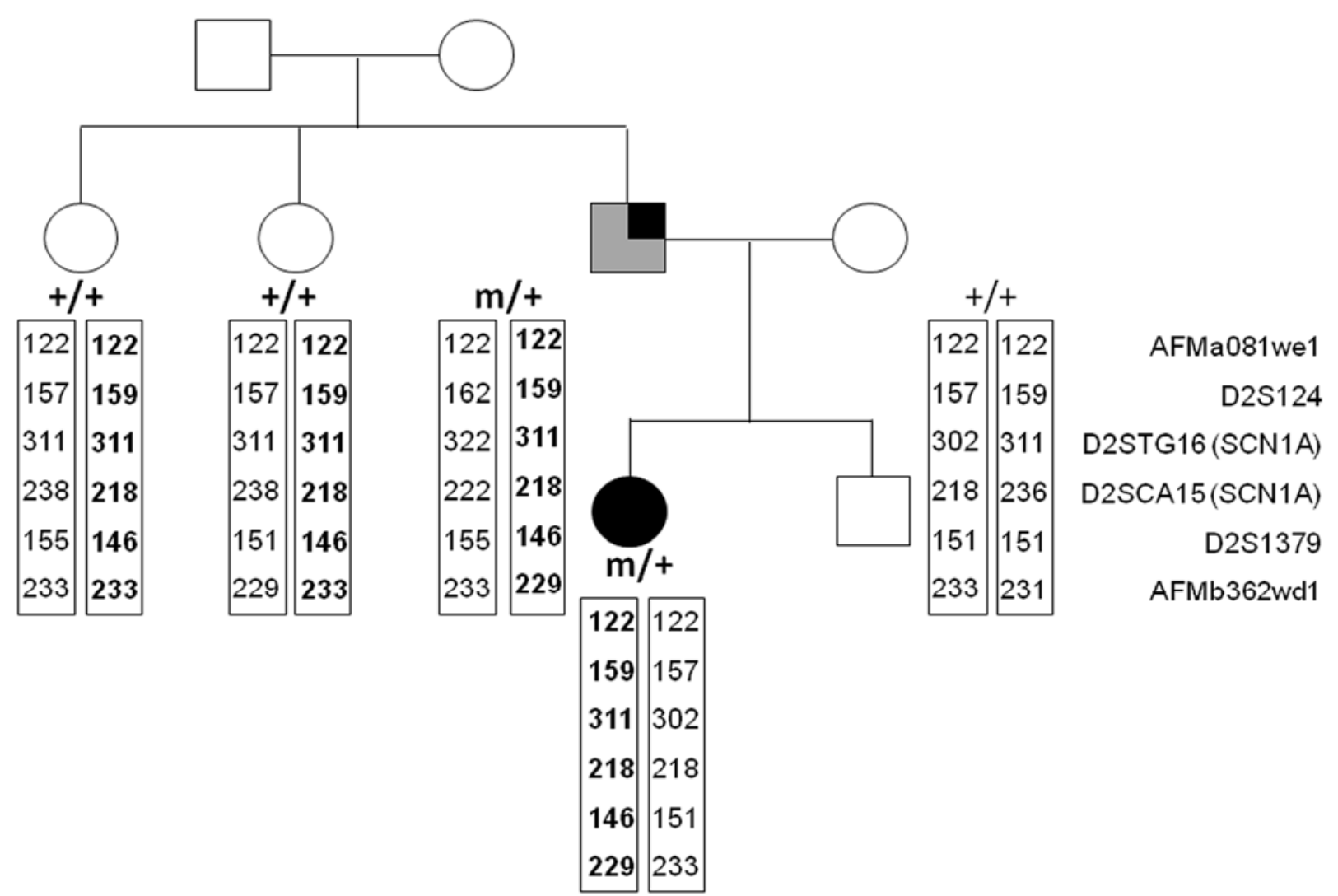



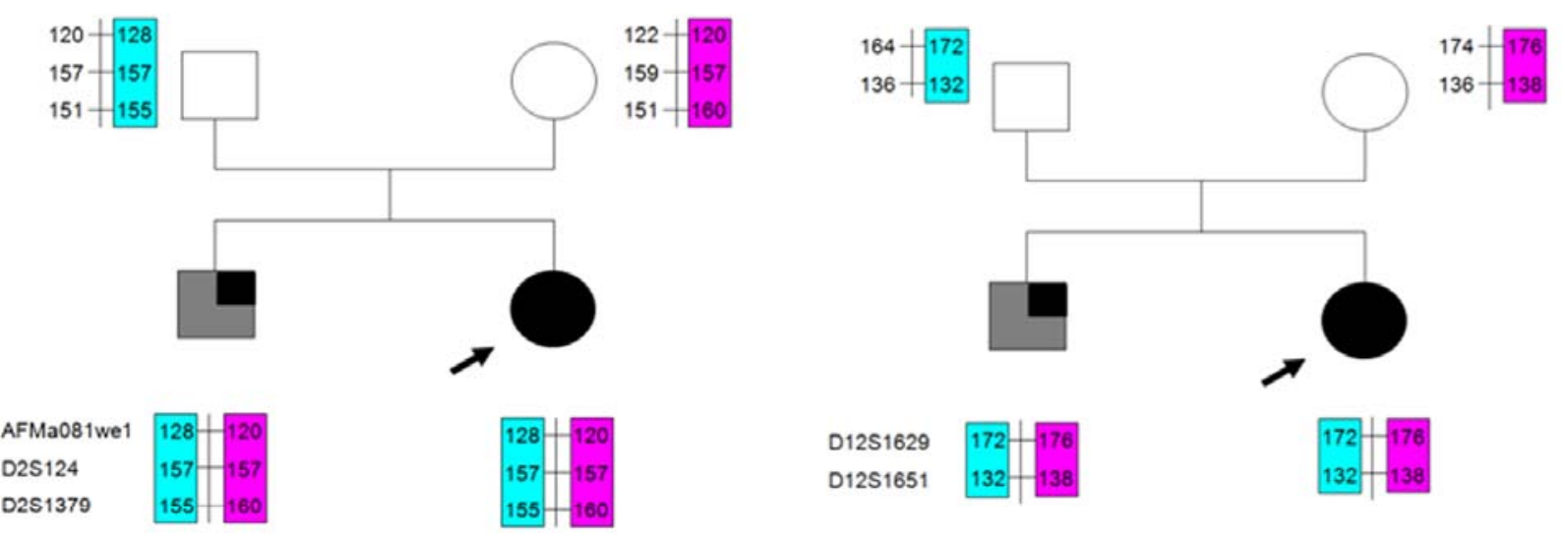

SCN1A/SCN9A

SCN8A 

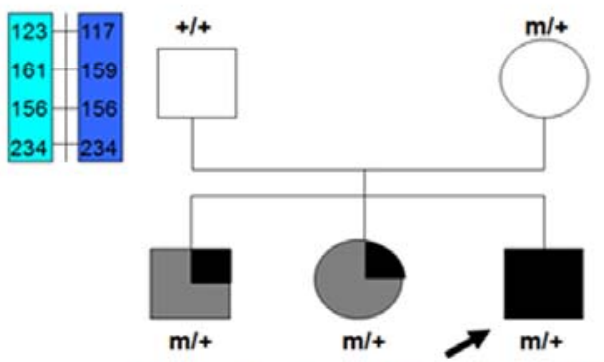

AFMa081we 1 D2S124 D2S1379 AFMb362wd1

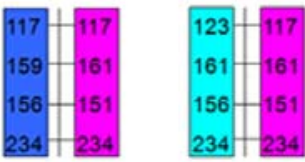

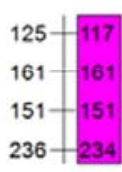

SCN1A/SCN9A

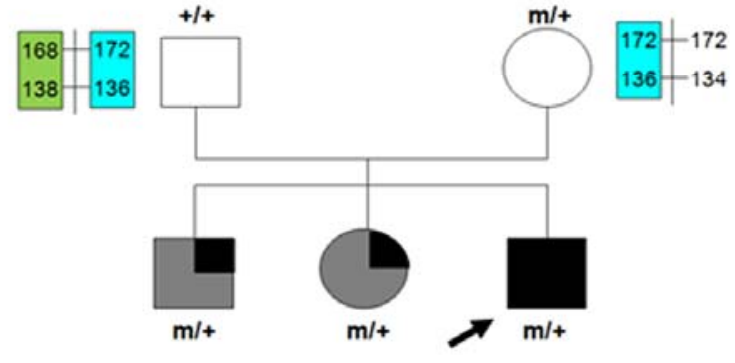

D12S1629 D12S1651

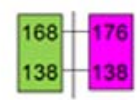

\begin{tabular}{|l|r|r}
\hline 172 & 176 \\
136 & 138 \\
\hline
\end{tabular} \begin{tabular}{|l|l|l|}
\hline 172 & 176 \\
136 & 138 \\
\hline
\end{tabular} 